\title{
TEKNOLOGI PENINGKATAN PRODUKSI UTAMA DAN BRANGKASAN JAGUNG DENGAN PENGGUNAAN VARIETAS UNGGUL DAN KOMPOS PADA LAHAN KERING DI NUSA TENGGARA BARAT
}

\author{
Budy Wiryono, Suwati dan Muliatiningsih \\ Program Studi Teknik Pertanian, Faperta UM Mataram \\ Jl. KH. Ahmad Dahlan No. 1 Pagesangan - Mataram \\ e-mail : budy0581@ummat.ac.id
}

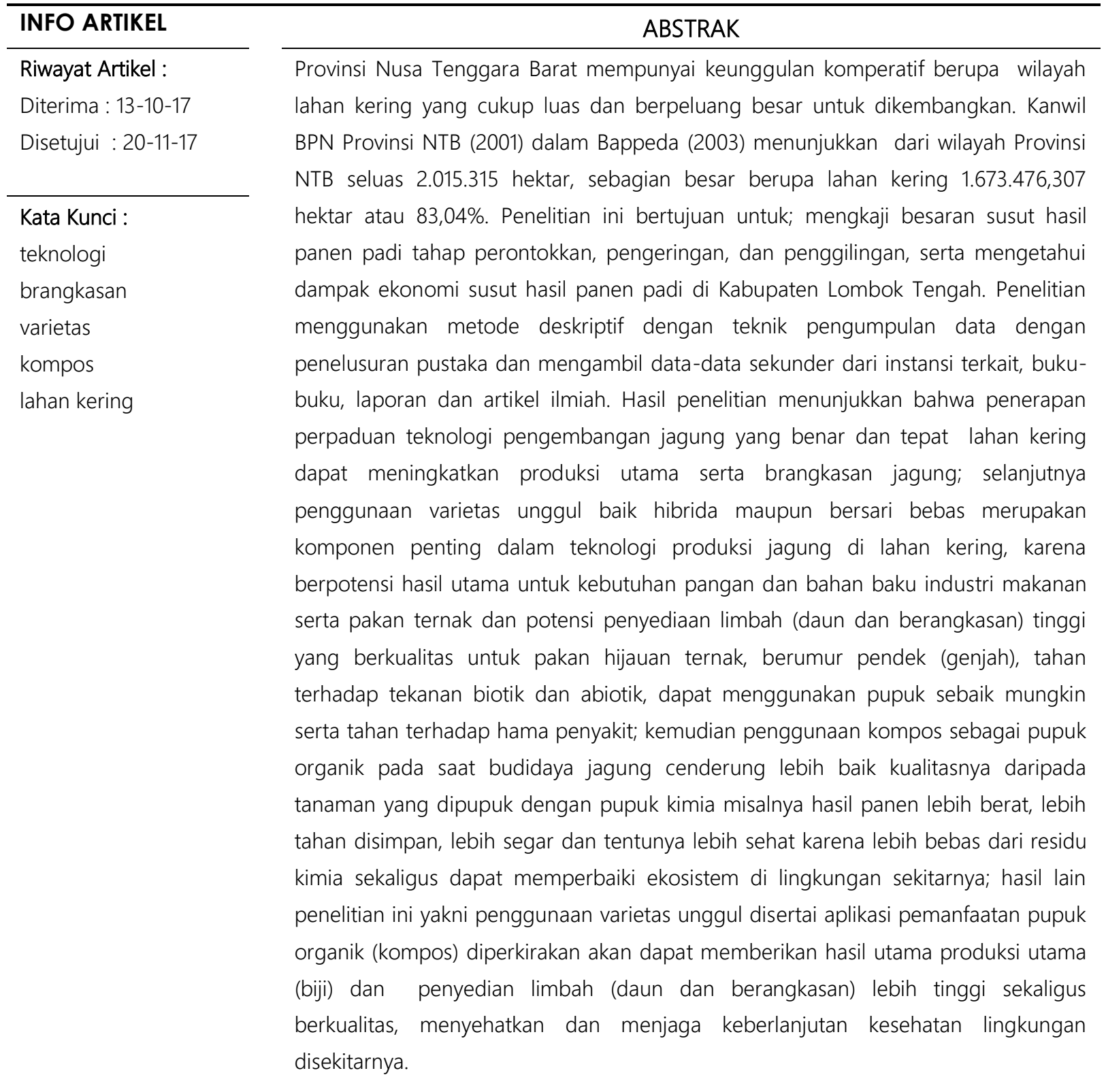




\section{A. LATAR BELAKANG}

Provinsi Nusa Tenggara Barat mempunyai keunggulan komperatif berupa potensi wilayah lahan kering yang cukup luas dan berpeluang besar untuk dikembangkan guna meningkatkan kesejahteraan masyarakat, terutama petani lahan kering. Data dari Kanwil BPN Provinsi NTB (2001) dalam Bappeda (2003) menunjukkan bahwa dari wilayah Provinsi NTB seluas 2.015.315 hektar, sebagian besar berupa lahan kering (1.673.476,307 hektar atau 83,04\%), sedang sisanya berupa lahan sawah dan penggunaan lain-lainnya (16,96\%).

Pendekatan dalam pengelolaan pertanian lahan kering tampaknya harus berorientasi pada pendekatan agroekosistem wilayah dengan tetap memperhatikan aspek sosial budaya spesifik daerah sebagai komponen pendekatan wilayah. Salah satu komoditas tanaman pangan yang cocok dan banyak diusahakan petani di lahan kering adalah jagung. Tanaman ini sangat bermanfaat bagi kehidupan manusia dan pengembangan ternak. Tanaman jagung merupakan komoditi tanaman pangan kedua terpenting setelah padi. Berdasarkan urutan bahan makanan pokok, jagung menduduki urutan ketiga setelah padi dan gandum. Jagung merupakan salah satu komoditas dari sub sektor tanaman pangan yang memiliki peran yang sangat penting dan strategis dalam pembangunan nasional. Peranan jagung dalam sub sektor tanaman pangan telah terbukti memberikan andil yang cukup besar terhadap ketahanan pangan dan juga terhadap perekonomian Indonesia. Dalam krisis ekonomi global tahun 1997 dan 2008, komoditas jagung telah menunjukkan ketangguhannya dan tetap tumbuh dengan angka positif dan menjadi penggerak bagi pertumbuhan industri hulu dan pendorong pertumbuhan industri hilir yang mempunyai kontribusi yang sangat besar terhadap pertumbuhan ekonomi nasional (Departemen Pertanian (2008) dalam Grand Strategi Pengembangan Agribisnis Jagung di NTB (2009-2013)).

Upaya peningkatan produksi dan produktivitas jagung di Nusa Tenggara Barat dapat melampaui target yang telah ditetapkan dalam Grand Startegi Pengembanan Agribisnis Jagung, bukan hanya dapat mencapai produktivitas 40-50 kuintal/hektar tetapi berdasarkan hasil penelitian Hipi et al (2005), produktivitas jagung di Sambelia dengan penerapan teknologi budidaya jagung bersari bebas Lamuru dapat mencapai produktivitas (potensi hasil) sebesar 54,5 kuintal/hektar, dengan potensi penyediaan limbah (daun dan brangkasan) sebesar 55,6 kuintal/hektar. Sedangkan berdasarkan kajian Badan Litbang Pertanian selama sepuluh tahun terakhir terhadap varietasvarietas jagung unggul bersari bebas produktivitasnya mencapai 70,0 - 85,0 kuintal/hektar dan untuk berbagai varietas jagung hibrida mencapai 85,0 - 11,0 kuintal/hektar (Balitbang Pertanian, 2007).

Dalam usaha tani jagung untuk mendapatkan tingkat produktivitas yang tinggi, kualitas yang baik, dan efisien maka penerapan teknologi produksi jagung melalui pendekatan pengelolaan tanaman secara terpadu (PTT-jagung) dengan memadukan berbagai komponen teknologi yang memberikan pengaruh sinergistik merupakan pendekatan yang sesuai, namun harus ditunjang dengan sistem kelembagaan yang memadai. Teknologi produksi yang dimaksud meliputi varietas unggul, benih bermutu, populasi tanaman yang optimal, pengelolaan hara dan air yang efisien, pengendalian jasad pengganggu dan teknologi pasca panen yang sesuai dengan kondisi lahan dan sosial ekonomi petani (Balitbang Pertanian, 2007).

Diantara komponen teknologi produksi jagung, varietas unggul (baik hibrida maupun bersari bebas) mempunyai peranan penting dalam upaya peningkatan produktivitas jagung. Peranannya menonjol baik dalam potensi peningkatan hasil per satuan luas maupun sebagai salah satu komponen pengendalian hama dan penyakit. Selain potensi produktivitas dan ketahanannya terhadap hama dan penyakit, karakter tanaman lain yang perlu dipertimbangkan dalam pemilihan varietas jagung unggul adalah kesesuaiannya dengan kondisi lingkungan (tanah dan iklim), antara lain toleran kekeringan dan tanah masam, serta preferensi petani terhadap karakter lainnya seperti umur dan warna biji (Balitbang Pertanian, 2007). Namun demikian distribusi varietas unggul masih berjalan lambat, yaitu hanya mencapai $80 \%$ pada tahun 2001, yang terdiri dari $24 \%$ hibrida dan $56 \%$ jagung bersari bebas (Pingali and Pandey, 2001). Lebih lanjut lagi menurut Nugraha, et al (2003), hasil survei tahun 2000 di 19 provinsi menunjukkan bahwa penggunaan benih jagung di Indonesia adalah $47 \%$ jenis komposit unggul, $28 \%$ hibrida dan 25\% komposit lokal. Dari 27\% penggunaan hibrida sebagian menggunakan benih hibrida hasil regenerasi.

Selain penggunaan varietas unggul yang dapat meningkatkan produktivitas pertanian, untuk melaksanakan sistem pertanian yang berkelanjutan penggunaan pupuk organik seperti biokompos dapat digunakan untuk meningkatkan kesuburan tanah sekaligus menjaga keseimbangan ekosistem dalam tanah, karena sangat tidak bijak apabila kita memaksakan peningkatan produksi pertanian tanpa memperhatikan keseimbangan ekosistem disekitarnya.

Hal paling utama yang melandasi usaha peningkatan produksi jagung khususnya di NTB adalah besarnya kuantitas pasar yang dapat dikelola oleh pelaku agribisnis jagung di NTB. Selama ini para petani sering mengeluhkan akan ketersediaan pasar dari komoditi yang mereka budidayakan, tanpa ketersediaan pasar maka produksi jagung yang melimpah justru akan 
merugikan petani, dan harga di pasaran lokal pasti akan rendah. Berdasarkan Grand Strategi Pengembangan Agribisnis Jagung tahun 2009-2013, didapat data dan informasi bahwa salah satu pembeli jagung yang aktif sampai saat ini adalah PT Wonokoyo, dimana pada awal tahun 2009 secara lisan perusahaan ini menyampaikan permintaan akan jagung NTB sebesar 45.00o ton per bulan atau 540.000 ton per tahun, selain itu pengusaha Korea Selatan yang sanggup bermitra dengan perusahaan lokal NTB juga bersedia membeli jagung NTB sebesar 580.000 ton per tahun. Selain itu pada tahun 2009 Dinas Pertanian Tanaman Pangan dan Hortikultura juga menyampaikan telah berhasil meyakinkan iPasar untuk membuka jaringannya di NTB, yaitu perusahaan swasta nasional yang menyelenggarakan pasar komoditas fisik yang menjajakan komoditas pertanian, perkebunan dan pertambangan di Indonesia melalui transaksi internet, dan pada lelang pertama di penghujung tahun 2009 telah terjual 300 ton jagung pipl kering dengan harga pasar yang kompetitif.

Melihat peluang yang begitu besar baik dari aspek ketersediaan lahan dan kesesuaian lahan di NTB serta permintaan akan jagung yang sangat tinggi maka Topik Khusus ini mengkaji peluang dan tantangan pengembangan jagung untuk peningkatan produksi serta ketersediaan bahan pakan ternak di wilayah lahan kering di NTB dari segi ketersediaan lahan, varietas unggul yang relevan dan penggunaan kompos.

\section{B. METODE PENELITIAN}

Metode yang digunakan dalam penelitian ini adalah metode deskriptif dengan teknik pengumpulan data dengan penelusuran pustaka dan mengambil data-data sekunder dari instansi terkait, buku-buku, laporan dan artikel ilmiah. Metode deskriptif dimaksudkan untuk menggambarkan peranan varietas dalam meningkatkan produktivitas jagung dan peranan kompos untuk meningkatkan kesuburan tanah. Data sekunder yang dihimpun dari instansi terkait, laporan, artikel ilimiah dan buku-buku berkaitan dengan pengelolaan budidaya tanaman jagung, potensi pengembangan jagung di lahan kering, produksi utama dan ikutan jagung serta peluang pasar jagung.

Cara penarikan kesimpulan dilakukan dengan metode deduksi. Metode deduksi dilakukan melalui pembuatan pernyataan yang bersifat umum kemudian dibuktikan dengan fakta-fakta yang bersifat khusus.

\section{HASIL DAN PEMBAHASAN}

\section{Upaya Pengembangan Jagung di Lahan Kering}

Pemanfaatan potensi lahan kering yang ada guna pengembanagn tanaman jagung harus ditempuh dengan melakukan identifikasi berbagai permasalahan baik biofisik maupun sosial ekonomi dan budaya melalui pendekatan partisipatif serta mengatasi permasalahan aktual dengan menerapkan pendekatan pengelolaan tanaman secara terpadu yang spesifik lokasi. Hal ini disebabkan karena masing-masing wilayah di NTB memiliki pola-pola tertentu dalam usaha tani serta topografi lahan yang berbeda di masing-masing wilayah tentu akan mempengaruhi cara bercocok tanam yang dilakukan oleh petani, sehingga teknologi-teknologi baru yang akan dikembangkan di suatu wilayah dalam upaya peningkatan produksi maupun produktivitas jagung harus disesuaikan dengan kondisi lingkungan setempat.

Keberhasilan produksi tanaman di lahan kering sangat dipengaruhi oleh kondisi curah hujan (intensitas, frekuensi) dan tanah (Pariera, 1983 dalam Wangiyana, 1995). Untuk mengatasi permasalahan pokok di lahan kering ini yaitu dengan penyesuaian tipe iklim, komoditas yang sesuai dan teknologi yang cocok. Strategi yang sesuai untuk menjamin keberhasilan adalah dengan memanfaatkan curah hujan, hari hujan serta periode hujan selama musim hujan (OktoberMaret) dengan mengatur pola tanam yang tepat dengan tanaman yang berumur pendek (genjah) sehingga dapat ditanam lebih dari sekali tanam (meningkatkan intensitas penanaman).

Dinas Pertanian Tanaman Pangan dan Hortikultura, (2009) menyatakan bahwa dalam upaya peningkatan produksi jagung di masa yang akan datang maka diperlukan langkah-langkah antara lain: penyediaan sarana produksi secara enam tepat dan gerakan penerapan teknologi anjuran seperti penggunaan benih bermutu, perbaikan pola tanam, pemupukan berimbang, Pengelolaan Hama Terpadu, pasca panen yang baik serta alat dan mesin pertanian dan permodalan. Disamping itu diperlukan daya dukung yang optimal terhadap pencapaian sasaran produksi melalui pendekatan agribisnis yang diarahkan untuk meningkatkan pendapatan petani, menyediakan kesempatan kerja yang produktif, memantapkan struktur kelembagaan perekonomian di pedesaan, menumbuhkembangkan perusahaan-perusahaan agribisnis di pedesaan dan memantapkan swasembada dalam rangka memenuhi permintaan pasar dalam dan luar negeri.

Sedangkan dari sisi budidaya tanaman, seluruh prinsip-prinsip budidaya tanaman harus dipahami yaitu pengetahuan agroekosistem, pertanaman campuran dan diversifikasi, kesesuaian bentuk lahan, pergiliran tanaman, irama alam dan saat tanam yang tepat, pemupukan dan kesehatan tanaman, pengolahan tanah, pemilihan varietas, kesehatan tanah, gatra sosial dan pengendalian hama dan penyakit secara alami. Dengan penerapan prinsip-prinsip budidaya seperti ini peningkatan produksi yang diharapkan dapat tercapai sekaligus terjadi keseimbangan dalam lingkungan hidup di tempat tanaman tersebut karena penggunaan input kimia yang sangat minim dan hanya dilakukan jika 
gangguan hama maupun penyakit telah berpotensi untuk mengurangi produksi, sehingga pertanian yang kita lakukan adalah yang ramah lingkungan dan sehat untuk alam dan makhluk hidup di dalamnya.

Pemilihan teknik pengairan juga sangat mempengaruhi produksi yang dihasilkan, dengan sistem pengairan yang tepat kita dapat menghemat air, melindungi tanaman jagung dari kejenuhan akan air yang dapat menyebabkan tanaman menjadi layu dan mati yang pada dasarnya hanya merupakan inefisiensi air/pemborosan karena air terbuang percuma tidak dapat dimanfaatkan oleh tanaman, salah satunya seperti yang dikembangkan di Lombok Utara yaitu menggunakan teknik irigasi sprinkler dapat menghemat hingga $85 \%$ penggunaan air dari sistem irigasi konvensional/leb dan dapat meningkatkan produksi jagung menjadi 7,34 ton/ha dibandingkan sistem irigasi konvensional/leb 2,76-3,25 ton/hektar.

\section{Penggunaan Varietas Unggul Jagung}

Peningkatan produktivitas dan produksi jagung dapat dipicu dengan penerapan teknologi tepat guna. Di Korea Selatan dengan menggunakan jagung varietas unggul dapat dihasilkan tingkat produktivitas jagung rata-rata 6,14 ton/hektar, sedangkan di RRC 3,85 ton/hektar. Sementara di Indonesia tingkat produktivitas jagung nasional rata-rata di bawah 3,0 ton/hektar (Rukmana, 2007), penelitian Sri Agung, 2008, pada lahan kering Kabupaten Badung- Bali mencapai 6,28 ton/hektar sedangkan penelitian Hipi et al, 2008 yang dilakukan di Kecamatan Sambelia Kabupaten Lombok Timur mencapai 5,45 ton/hektar.

Rendahnya hasil rata-rata jagung nasional disebabkan oleh banyak faktor. Beberapa faktor diantaranya adalah belum meluasnya penanaman varietas-varietas unggul dan belum memperhatikan penggunaan benih berkualitas di tingkat petani. Jagung varietas unggul mempunyai potensi hasil antara 4,5-5,7 ton/hektar, sedangkan varietas jagung hibrida dapat mencapai lebih dari 6,o ton/hektar (Rukmana, 2007)

Diantara komponen teknologi produksi jagung, varietas unggul (baik hibrida maupun bersari bebas) mempunyai peranan penting dalam upaya peningkatan produktivitas jagung. Peranannya menonjol baik dalam potensi peningkatan hasil per satuan luas maupun sebagai salah satu komponen pengendalian hama dan penyakit. Selain potensi produktivitas dan ketahanannya terhadap hama dan penyakit, karakter tanaman lain yang perlu dipertimbangkan dalam pemilihan varietas jagung unggul adalah kesesuaiannya dengan kondisi lingkungan (tanah dan iklim), antara lain toleran kekeringan dan tanah masam, serta preferensi petani terhadap karakter lainnya seperti umur dan warna biji. Hal ini terbukti dari hasil penelitian-penelitian sebelumnya seperti yang telah diuraikan di atas, hal ini juga pasti dapat terjadi pada lahan kering lainya yang ada di Nusa Tenggara Barat, sehingga dengan semakin banyak varietas unggul yang dilepas dan tersedia di tingkat petani dengan karakter spesifik yang sesuai dengan kondisi lingkungan setempat semakin memudahkan petani mengambil keputusan untuk menentukan suatu varietas yang sesuai dengan sumber daya yang ada di lingkungannya untuk menigkatkan hasil produksi utama maupun penyediaan limbah untuk pakan ternak di Nusa Tenggara Barat.

\section{Penggunaan Pupuk Organik (Kompos)}

Dalam upaya peningkatan produksi dan produktivitas jagung di lahan kering sekaligus dalam upaya untuk memperbaiki kondisi fisik dan biologis lahan menuju pertanian yang berkelanjutan salah satunya adalah dengan mengurangi segala bentuk input kimia, termasuk meminimalisasi penggunaan pupuk kimia dan digantikan dengan pupuk organik (kompos).

Kompos adalah jenis pupuk organik yang terjadi karena proses penghancuran oleh alam atau buatan atas bahan-bahan organik. Pengomposan merupakan proses dimana bahan organik mengalami penguraian secara biologis, khususnya oleh mikroba-mikroba yang memanfaatkan bahan organik sebagai sumber energi. Kompos dapat memperbaiki struktur tanah dengan meningkatkan kandungan bahan organik tanah dan akan meningkatkan kemampuan tanah untuk mempertahankan kandungan air tanah.Aktivitas mikroba tanah yang bermanfaat bagi tanaman akan meningkat dengan penambahan kompos. Aktivitas mikroba ini membantu tanaman untuk menyerap unsur hara dari tanah dan juga dapat membantu tanaman menghadapi serangan penyakit. Tanaman yang dipupuk dengan kompos cenderung lebih baik kualitasnya dibandingkan tanaman yang dipupuk dengan pupuk kimia, seperti hasil panen lebih tahan disimpan, lebih berat, lebih segar lebih enak dan tentunya lebih sehat bagi tubuh manusia karena produk dihasilkan dari media yang sehat.

Peran bahan organik terhadap sifat fisik tanah diantaranya merangsang granulasi, memperbaiki aerasi tanah dan meningkatkan kemampuan menahan air. Peran bahan organik terhadap sifat biologis tanah adalah meningkatkan aktivitas mikroorganisme yang berperan pada fiksasi nitrogen dan transfer hara tertentu seperti N, P dan S. Peran bahan organik terhadap sifat kimia tanah adalah meningkatkan kapasitas tukar kation sehingga mempengaruhi serapan hara oleh tanaman (Gaur, 1980 dalam Wikipedia Indonesia 2009).

Selain kelebihan seperti dalam uraian di atas, pupuk organik juga memiliki kelemahan, diantaranya (i) diperlukan dalam jumlah yang sangat banyak untuk memenuhi kebutuhan unsur hara dari suatu pertanaman, (ii) bersifat ruah, baik dalam pengangkutan dan penggunaannya di lapangan dan (iii) kemungkinan akan menimbulkan kekahatan unsur hara apabila bahan 
organik yang diberikan belum cukup matang (Sutanto, 2002).

Penggunaan pupuk organik yang lebih mudah kiranya akan lebih meningkatkan ketertarikan petani untuk beralih menggunakan pupuk organik dibandingkan anorganik, karena hasil produksi bisa lebih tinggi, aplikasi dan ketersdiaannya mudah dipahami dan didapat oleh petani sepanjang waktu, minimal pola pikir yang selama ini tertanam pada petani bahwa penggunaaan pupuk anorganik satu-satunya cara untuk meningkatkan kesuburan tanah dan menghasilkan produksi lebih tinggi dapat berubah, secara perlahan apa yang kita harapkan untuk terciptanya pertanian berkelanjutan di seluruh provinsi ini akan terwujud sehingga kualitas lingkungan hidup dengan seluruh ekosistem didalamnya dapat menjadi lebih sehat dan lebih baik.

\section{Kombinasi Penggunaan Varietas Unggul dan Kompos}

Penggunaan varietas unggul yang mempunyai karakteristik mampu meningkatkan produksi jagung persatuan luas lahan baik produksi utama sebagai sumber bahan makanan maupun brangkasan untuk pakan ternak akan sangat baik jika dikombinasi dengan penggunaan kompos sebagai pupuk organik, karena kompos akan memperbaiki struktur tanaj hingga daya serap akar tehadap nutrisi dalam bentuk unsur hara makro $(\mathrm{N}, \mathrm{P}, \mathrm{K})$ akan semakin besar, kompos juga dapat memperkuat pertumbuhan akar, sehingga pada saat tanaman sudah mencapai tahap pertumbuhan lebih dari 40 hari setelah tanam dalam kondisi tanaman berat apabila terjadi angin kencang tanaman tidak akan roboh. Selain menghasilkan produksi utama yang lebih baik, dengan penggunaan kompos akan menghasilkan brangkasan jagung sebagai bahan pakan ternak dengan kualitas nutrisi yang lebih baik. Nutrisi yang terkandung dalam pakan ternak berupa karbohidrat, lemak, protein, vitamin dan mineral merupakan unsur penting untuk menjamin kesehatan ternak, pertumbuhan badan yang optimal dan kesehatan reproduksi. Sapi muda memerlukan jumlah pakan yang terus meningkat sampai dicapai pertumbuhan badan yang maksimal. Sapi bunting memerlukan pakan dengan kandungan nutrisi yang lebih baik untuk pertumbuhan fetus. Pakan hijauan yang kaya akan berbagai nutrisi kualitas daging ternak.

Pada sentra peternakan sapi perah di Pangalengan (Jawa Barat), menyatakan bahwa dalam sehari rata-rata satu ekor sapi memerlukan pakan hijuan sebanyak 40 $\mathrm{kg}$, sehingga dapat kita perkirakan berapa banyak kebutuhan pakan hijauan ternak apabila Program Bumi Sejuta Sapi (BSS) yang dicanangkan Pemerintah Provinsi NTB mulai berjalan.

\section{Limbah Jagung Sebagai Pakan Ternak}

Hampir semua bagian tanaman jagung dapat dimanfaatkan untuk kepentingan manusia dan hewan. Hasil utamanya berupa buah dan bijinya dapat digunakan sebagai bahan makanan manusia. Biji jagung juga digunakan dalam industri pengolahan makanan dan minuman, industri farmasi, dextrin termasuk perekat dan industri kecil, sedangkan hasil sampingan jagung berupa batang, daun dan hasil ikutan dimanfaatkan untuk pakan ternak.

Di bidang industri pakan ternak, hasil sampingan(ikutan) merupakan bahan pencampur penting sebagai sumber karbohidrat dan nutrisi lain, katul (bekatul) dapat dimanfaatkan untuk ternak ruminansia seperti sapi, kerbau, domba dan kambing, karena mengandung gizi cukup tinggi dan lengkap, tiap 100 gram bahan terdiri atas kandungan kalori 356,0 kal, protein 9,0 g, lemak 8,5 g, karbohidrat $64,5 \mathrm{~g}$, kalsium $200 \mathrm{mg}$, fosfor $500 \mathrm{mg}$, zat besi $10 \mathrm{mg}$, vitamin B1 1,2 mg dan bagian yang dapa dimakan 100\% ( Rukmana, 2007). Batang dan daunnya yang masih muda digunakan untuk makanan ternak, sedangkan yang sudah tua digunakan untuk pupuk hijau atau pupuk kompos.

Batang, daun dan hasil ikutan jagung yang mengandung komposisi dan zat gizi lengkap tentunya akan sangat baik bagi kesehatan ternak, meningkatkan pertumbuhan dan kualitas ternak, karena sumber makanannya telah mengandung unsur-unsur yang dibutuhkan untuk pertumbuhan. Dengan di kembangkannya Program Bumi Sejuta Sapi (BSS) di Nusa Tenggara Barat, sangat dibutuhkan ketersediaan bahan pakan ternak baik segar maupun olahan untuk menjamin ketersediaan makanan sapi sepanjang tahun dengan kuantitas dan kualitas yang baik. Dengan peningkatan produksi jagung yang dilakukan melalui berbagai teknik budidaya secara tidak langsung kita juga telah menyediakan bahan makanan/pakan untuk ternak, khususnya sapi, sehingga program-program unggulan berupa PIJAR (Sapi, Jagung dan Rumput Laut) akan lebih cepat berhasil.

\section{Pertanian yang Berkelanjutan}

Sebenarnya dalam ekosistem sudah terdapat komponen biotik baik flora maupun fauna yang menyediakan jasa ekologi seperti proses dekomposisi bahan organik (daur ulang unsur hara) guna mempertahankan kesuburan tanah. Alam juga menyediakan pengatur dan pengendali populasi hama dan penyebab penyakit tanaman, menyediakan proses penyerbukan oleh serangga/hewan penyerbuk yang menjaga keberlanjutan reproduksi tanaman. Kesemuanya ini berinteraksi secara evolusi ekosistem apabila satu komponen hilang akan timbul goncangan ekologi yang ditandai dengan pelonjakan salah satu komponen (misalnya hama), atau proses pengembangan ekosistem berjalan tidak normal (misalnya karena input 
pestisida dan kimia yang berlebihan, tanah menjadi tidak gembur karena kehilangan mikroba pengurai).

Pertanian berkelanjutan menurut konsepsi Serikat Petani indonesia (SPI) ialah salah satu cara bertani yang mengintegrasikan secara komprehensif aspek lingkungan hingga sosial ekonomi masyarakat pertanian dengan tujuan untuk memutus ketergantungan petani terhadap input eksternal dan penguasa pasar yang mendominasi sumber daya agraria. Dengan demikian pertanian berkelanjutan merupakan suatu pilihan lain selain pertanian modern yang menggunakan masukan (input) dari luar seperti pupuk pabrik, bibit pabrik, pestisida dan herbisida kimia pabrik yang umumnya merusak kelestarian tanah dan alam. Sebaliknya pertanian berkelanjutan lebih mengandalkan pemanfaatan sumber daya yang tersedia seperti bibit lokal, sumber air, matahari dan teknologi ramah lingkungan serta pemanfaatan pupuk kandang/kompos dan pengendali hama alami atau pestisida dari bahanbahan alami (Mediansyah, 2009).

Selama ini indikator sukses pertanian kita adalah sekedar jumlah atau hasil produksi pertanian, untuk memenuhi permintaan pasar. Dalam pertanian berkelanjutan, tujuan yang ingin dicapai bukanlah hanya target produksi jangka pendek, tetapi lebih ditekankan pada upaya keberlanjutan sistem produksi jangka panjang. Sehingga inovasi yang dilakukan, dalam pertanian berkelanjutan adalah dalam rangka peningkatan secara optimal proses-proses biologi dan ekologi dalam ekosistem.

Untuk inilah, kini saatnya (terutama) para penyuluh pertanian untuk mengajari petani kita (yang sudah lupa) cara-cara mengembangkan kesuburan tanah, prinsip pengendalian hama alami dan pengoptimalisasi peran musuh alami, pengelolaan tanaman (memilih jenis, pola tanam, mengatur waktu tanam yang tepat) guna memanipulasi interaksi musim-tanaman-hama. Hal lain, harus dipikirkan pula pengembangan jenis-jenis kultivar tanaman yang tidak rakus pupuk dan relative tahan terhadap hama dan penyakit. Pengembangan varietas unggul lokal (yang sudah beradaptasi sesuai dengan kondisi setempat) perlu dipertimbangkan untuk mendapatkan bibit unggul spesifik lokasi.

Kiranya, masih ada harapan di Indonesia khususnya di Nusa Tenggara Barat untuk mempertahankan keberadaan ekosistem pertanian, memelihara potensinya untuk jangka waktu lama, tidak berdampak negatif pada lingkungan.

\section{KESIMPULAN DAN SARAN}

Terbatas pada pembahasan maka dapat ditarik simpulan sebagai berikut :

Penerapan perpaduan teknologi pengembangan jagung yang benar dan tepat lahan kering dapat meningkatkan produksi utama serta brangkasan jagung;
Penggunaan varietas unggul baik hibrida maupun bersari bebas merupakan komponen penting dalam teknologi produksi jagung di lahan kering, karena berpotensi hasil utama untuk kebutuhan pangan dan bahan baku industri makanan serta pakan ternak dan potensi penyediaan limbah (daun dan berangkasan) tinggi yang berkualitas untuk pakan hijauan ternak, berumur pendek (genjah), tahan terhadap tekanan biotik dan abiotik, dapat menggunakan pupuk sebaik mungkin serta tahan terhadap hama penyakit;

Penggunaan kompos sebagai pupuk organik pada saat budidaya jagung cenderung lebih baik kualitasnya daripada tanaman yang dipupuk dengan pupuk kimia misalnya hasil panen lebih berat, lebih tahan disimpan, lebih segar dan tentunya lebih sehat karena lebih bebas dari residu kimia sekaligus dapat memperbaiki ekosistem di lingkungan sekitarnya;

Penggunaan varietas unggul disertai aplikasi pemanfaatan pupuk organik (kompos) diperkirakan akan dapat memberikan hasil utama produksi utama (biji) dan penyedian limbah (daun dan berangkasan) lebih tinggi sekaligus berkualitas, menyehatkan dan menjaga keberlanjutan kesehatan lingkungan disekitarnya.

\section{DAFTAR PUSTAKA}

[1]. Biro Pusat Statistik, 1996. Survei susut pascapanen MT. Balitbang Pertanian, 2007. Teknologi Produksi Jagung Melalui Pendekatan Pengelolaan Sumber Daya dan Tanaman Terpadu (PTT). Deptan RI.Jakarta. Hal 75-79;

[2]. Bappeda Propinsi NTB, 2003. Rencana Strategis Pengembangan Wilayah Lahan Kering Propinsi NTB Tahun 2003-2007;

[3]. BPS NTB, 2010. Press Rilis Angka Tetap Tahun 2009 dan Angka Ramalan II Tahun 2010 Produksi Tanaman Pangan Provinsi NTB;

[4]. Dahlan, M., 1988. Pembentukan dan Produksi Benih Varietas Bersari Bebas Dalam Subandi, Mahyudin Syam dan Adi Wijono (eds) Jagung. Puslitbangtan. Bogor. Hal 101-118;

[5]. Dinas Pertanian Tanaman Pangan dan Hortikultura Provinsi NTB, 2009. Program Unggulan Dinas Pertanian Tanaman Pangan dan Hortikultura Provinsi NTB;

[6]. Grand Strategi Pengembangan Agribisnis Jagung di NTB (2009-2013). Membumikan Jagung Merebut Pasar.

[7]. Hipi, A., Suriadi A, Zairin M, Sudarto, Mashur dan Suwardji, 2004. Teknologi Budidaya Jagung di Lahan Kering Beriklim Kering di Kabupaten Lombok Timur;

[8]. Hipi, A., 2008. Peluang dan Tantangan Pengembangan Jagung di Lahan Kering di NTB;

[9]. Ma'shum, M., Lolita, E.S dan Sukartono, 2002. Strategi Pengelolaan Lahan Kering Berwawasan Lingkungan di NTB. Prosiding Seminar Nasional Peningkatan Pendapatan Petani Miskin Melalui Pemanfaatan Sumber Daya Pertanian dan Penerapan Teknologi Tepat Guna. 
BPTP NTB, Badan dan Pengembangan Pertanian, Departemen Pertanian;

[10].Mediansyah, 2009. IPTEK. Pertanian Berkelanjutan adalah Masa Depan Kita;

[11]. Nugraha, U., A. Hasanuddin dan Subandi, 2003. Perkembangan Teknologi Budidaya Jagung dan Industri Benih Jagung. Dalam Kasryno, E. Pasandaran dan A.M.Fagi (ed) Ekonomi Jagung Indonesia. Penyunting Badan Penelitian dan Pengembangan Pertanian Departemen Pertanian. Jakarta. Hal 37-72;

[12]. Pingali, P.L and S. Pandey, 2001. Meeting World Maize Need; Technological Oppurtunities and Priorities For The Public Sector. Dalam Pingali, P.B (Ed) Meeting World Maize Needs; Technological Oppurtunities and Priorities For The Public Sector;

[13]. Rukmana, R., 2007. Jagung. Budidaya, Pasca Panen dan Penganekaragaman Pangan. Penerbit CV. Aneka Ilmu. Edisi 1. Semarang;

[14]. Sri Agung, I. G. A. M, 2008. Adaptasi Berbagai Varietas Jagung Dengan Densitas Berbeda Pada Akhir Musim Hujan Di Jimbaran Kabupaten Badung. Laporan Penelitian. Universitas Udayana Press. Denpasar;

[15]. Sutanto, R., 2002. Penerapan Pertanian Organik. Pemasyarakatan dan Pengembangannya. Penerbit Kanisius Yogyakarta;

[16]. Suwardji, Ridwan D., Agustina D. A., Sapei G., 2008. Penggunaan Irigasi Sprinkler Untuk Pengembangan Pertanian Lahan Kering Dengan Pendekatan 4P (Studi Kasus NTB);

[17]. Suwardji, 2009. Diktat Pengelolaan Sumber Daya Lahan Kering. Program Pasca Sarjana Fakultas Pertanian Universitas Mataram. Mataram;

[18].Utomo, 2002. Pengelolaan Lahan Kering Untuk Pertanian Berkelanjutan. Makalah Utama Pada Seminar Nasional IV. Pengembangan Wilayah Lahan Kering dan Pertemuan Ilmiah Tahunan Himpunan Ilmu Tanah Indonesia di Mataram, 27-28 Mei 2002;

[19]. Walimin, 2009. Pengelolaan Tanaman Jagung Secara Terpadu. Penyuluh Pertanian Penyelia Pada Cabang Dinas PKP Demak I;

[20]. Wangiyana, W., 1995. Pewilayahan Komoditas Tanaman Berdasarkan Kondisi Iklim; Suatu Tinjauan Permasalahan dan Prospek Jangka Panjangnya. Prosiding Seminar 30 Nopember 1995. Universitas Mataram Press. Mataram;

[21]. Wikipedia Bahasa Indonesia, Ensiklopedia Bebas. Kompos. Manfaat Kompos. http://www.wikipediadefinisi-kompos/diakses tanggal 12 April 2018. 